Article

\title{
Vegetation Coverage Prediction for the Qinling Mountains Using the CA-Markov Model
}

\author{
Lu Cui ${ }^{1}$, Yonghua Zhao ${ }^{1, *}$, , Jianchao Liu ${ }^{1}$, Huanyuan Wang ${ }^{2}$, Ling Han ${ }^{1}, \mathrm{Juan} \mathrm{Li}^{2}$ and Zenghui Sun ${ }^{2}$ \\ 1 Shaanxi Key Laboratory of Land Consolidation, The School of Earth Science and Resources, The School of \\ Land Engineering, Chang'an University, Xi'an 710054, China; cuilu@chd.edu.cn (L.C.); \\ ljchao@chd.edu.cn (J.L.); hanling@chd.edu.cn (L.H.) \\ 2 Key Laboratory of Degraded and Unused Land Consolidation Engineering, The Ministry of Natural and \\ Resources, Shaanxi Provincial Land Engineering Construction Group Co., Ltd., Xi'an 710075, China; \\ wanghyuan@chd.edu.cn (H.W.); lijuan@chd.edu.cn (J.L.); sunzhui@chd.edu.cn (Z.S.) \\ * Correspondence: yonghuaz@chd.edu.cn
}

Citation: Cui, L.; Zhao, Y.; Liu, J.; Wang, H.; Han, L.; Li, J.; Sun, Z. Vegetation Coverage Prediction for the Qinling Mountains Using the CA-Markov Model. ISPRS Int. J. Geo-Inf. 2021, 10, 679. https:// doi.org/10.3390/ijgi10100679

Academic Editors: Niko Lukač, Marko Bizjak and Wolfgang Kainz

Received: 8 August 2021

Accepted: 5 October 2021

Published: 8 October 2021

Publisher's Note: MDPI stays neutral with regard to jurisdictional claims in published maps and institutional affiliations.

Copyright: () 2021 by the authors. Licensee MDPI, Basel, Switzerland. This article is an open access article distributed under the terms and conditions of the Creative Commons Attribution (CC BY) license (https:// creativecommons.org/licenses/by/ $4.0 /)$.
Abstract: The Qinling Mountains represent the dividing line of the natural landscape of northsouth in China. The prediction on vegetation coverage is important for protecting the ecological environment of the Qinling Mountains. In this paper, the data accuracy and reliability of three vegetation index data (GIMMS NDVI, SPOT NDVI, and MODIS NDVI) were compared at first. SPOT, NDVI, and MODIS NDVI were used for calculating the vegetation coverage in the Qinling Mountains. Based on the CA-Markov model, the vegetation coverage grades in 2008, 2010, and 2013 were used to simulate the vegetation coverage grade in 2025. The results show that the grades of vegetation coverage of the Qinling Mountains calculated by SPOT, NDVI, and MODIS NDVI are highly similar. According to the prediction results, the grade of vegetation coverage in the Qinling Mountains has a rising trend under the guidance of the policy, particularly in urban areas. Most of the vegetation coverage transit from low vegetation coverage to middle and low vegetation coverage. The grades of the vegetation coverage, which were predicted by the CA-Markov model using SPOT, NDVI, and MODI NDVI, are consistent in spatial distribution and temporal variation.

Keywords: the Qinling Mountains; vegetation coverage; CA-Markov

\section{Introduction}

As an important part of the global ecosystem, the vegetation plays an irreplaceable role in the ecological protection, ecological stability, and social environment [1,2]. Meanwhile, the vegetation reflects the impact of climate change and human activities on the regional ecological environment $[3,4]$. Vegetation coverage is the ratio of the vertical projection area of the vegetation to the unit area. It is a quantitative indicator of the growth of vegetation, which reflects the conditions of vegetation $[5,6]$. As a very important ecological climate parameter, vegetation coverage is also a comprehensive quantitative indicator for the surface condition of phytocoenosium, which is the basic data for studying regional or global issues in hydrology, meteorology, and ecology. It is widely used in the theories and models of geological disasters, geological structures, natural environment evolution, and soil and water conservation $[7,8]$. The prediction of vegetation coverage is important in geography and ecology. There are two methods, including ground measurement and remote sensing estimation, for obtaining the vegetation coverage. For the estimation of vegetation coverage in large areas, remote sensing technology has more advantages in terms of timeliness and economy [9]. The vegetation index (VI) is obtained with the multispectral remote sensing data. It reflects the vegetation information, such as vegetation growth and biomass [10], which is used to calculate the vegetation coverage. Currently, the normalized difference vegetation index (NDVI) is considered as the commonly used VI due to its high sensitivity and good temporal and spatial adaptability [11]. 
The cellular automata (CA) model is a local grid dynamic model with spatial interaction and time causality, which is discrete in time, space, and state [12-15]. It divides the areas into cells with the current states and the changing of their adjacent cells, which is based on the continuous development and surrounding change [16]. Furthermore, the CA model is widely used in land use changes, landform evolution, urban growth, and proliferation. Ding et al. [17] simulated the nonlinear features in the complex land-use changes of the Yellow River Delta (China) using the CA model with a multi-state artificial neutral network and a multi-state autologistic regression. Cao et al. [18] studied the selforganizing spatial growth process of Hangzhou (China) using a hybrid logistic CA model, which interpreted the converting tendency from non-construction land to construction land as the urban development purposes. Yang et al. [19] applied the CA model with artificial neutral network for simulating the land use change of the Changping district (Beijing, China), which integrated the landscape pattern indices. Valencia et al. [20] used a CA-based model to predict the urban growth of Quito (Ecuador) for urban planning. Kim et al. [21] researched the urban land use changed of Ansan (South Korea) using the patch-based CA model with urban green space policies. Ke et al. [22] simulated the multiple land uses of Wuhan (China) using a CA-based model with a calibrated allocation sequence and resistances. Lanzer et al. [23]. researched the vegetation dynamics of Atlantic Heathland (Netherlands) using the CA model. The primary advantage of CA is the simple and effective spatial modeling with the predefined transition rules, which was compatible with most spatial data for realizing virtually [24]. However, the modeling results relates with cell size and neighbor condition, which depend on the scale of the spatial model $[25,26]$.

The Markov model is a grid-based spatial probability model, which uses the transition between two previous period to predict the future transition. It is often used to predict geographical distributions $[27,28]$. The Markov model has no spatial variables in prediction, while the state variables of the CA model closely link to the spatial position $[29,30]$. Biswas et al. [31] studied the land-use-land-cover change of astern part of Kolkata (India) using the Markov model to depict the continuous urban growth. Ababneh et al. [32] used the Markov chain analysis to predicate the land use changes of Umm Oais (Jordan). Das et al. [33] researched the future land use distribution of the Bhagirathi-Hugli River (India) using the Markov model. Huang et al. [34] analyzed the interregional differences in land use in Beijing (China) using the Markov model for balancing urban expansion and ecological conservation. Paul et al. [35] predicted land use and land cover changes in the Kiskatinaw River Watershed (Canada) using Markov chain modeling, which was aided by object oriented image classification and neural network. Balzter et al. [36] investigated the Markov model on vegetation changes using several different data sets of Linden (Germany), Heiliges Meer (Germany), Zagreb (Croatian), and Giessen (Germany).

In order to utilize the advantages of the CA model and the Markov Model, the CAMarkov model is investigated to apply to the simulation and prediction of landscape pattern, land use and urban expansion. Behera et al. [37] researched the deforestation, agriculture expansion, and infrastructure of Choudwar watershed (India) using the CA-Markov model, which is used to predict the future land use scenario. Adhikari et al. [38] investigated the land use change of Bannerghatta National park (USA) using the CA-Markov model to predict the forest cover development. Chu et al. [39] researched the relationship between the biodiversity and the evolution of landscape pattern and habitat quality of the Three Gorges Reservoir Area in Hubei (China) by combining the CA-Markov and the InVEST model. Kityuttachai et al. [40] investigated the dynamic urban horizontal expansion of Hua Hin (Tailand) using the CA-Markov model for sustainable management. Sang et al. [41] studied the spatial pattern of land use of Fangshan district in Beijing (China) using the CA-Markov model. Shaar et al. [42] used a modified CA-Markov model to predict the land use pattern in Lebanon, which was more accurate than the extended Markov Chain model. Kamusoko et al. [43] studied land use/cover in Zimbabwe using the CA-Markov model for the sustainable rural land use planning. Tariq et al. [44] researched the urban growth tendency of Faisalabad (Pakistan) using the CA-Markov model, which was based on the 
prediction of seasonal land surface temperature and land use and land cover. Du et al. [45] researched the vegetation coverage of Shijiazhuang (China) using the CA-Markov model.

Therefore, the CA-Markov model not only has the ability to simulate the spatial changes of complex systems from the CA model, but also the ability to quantify predictions from the Markov model [46]. The CA-Markov model improves the simulation accuracy, and reduces the interference of human factors. Wu et al. [47] predicted the spatial position of the desert/grassland biome transition zone in Africa, based on the CA-Markov model with GIMMS and ERA5. Jamali et al. [48] researched the expansion of saline lands through vegetation and wetland loss using the CA-Markov model with NDVI. Wang et al. [49] analyzed the NDVI tempo-spatial variations in Weihe Watershed using the CA-Markov model.

However, there are few works to apply various NDVI on the CA-Markov model for simulation and analysis of vegetation coverage, especially for the Qinling Mountains. In this paper, three sources of NDVI data (GIMMS NDVI, SPOT NDVI, and MODIS NDVI) on the Qinling Mountains were compared and analyzed. For high reliability and feasibility, MODIS NDVI and SPOT NDVI were used to calculate and grade the vegetation coverage. Then, for the vegetation coverage grade, the CA-Markov model was combined with the vegetation index to simulate the vegetation coverage in the Qinling Mountains and to predict its dynamic change in 2025. This work can be a reference for studying the impact of vegetation change on the regional ecosystem in the Qinling Mountains, which provides a basis for reasonable landscape control strategies and sustainable management of the ecosystem.

\section{Materials and Methods}

\subsection{Research Area}

In this work, the research area is the part of the Qinling Mountains in Shaanxi Province. The Qinling Mountains represent the most important geological line between the north and south of China, which divide the climate of China as the subtropical humid climate and the warm-temperate semi-arid climate. The vegetation types on the north and south slopes of the Qinling Mountains are different. The northern slope is in the warm temperature zone. The vegetation is the warm temperate coniferous broad-leaved forest. The southern slope is in the north subtropical region. The vegetation is a mixed forest of north subtropical deciduous broad-leaved and evergreen broad-leaved forests. As shown in Figure 1, the research area of this paper is situated in $32^{\circ} 40^{\prime}-34^{\circ} 33^{\prime}$ north latitude and $106^{\circ} 03^{\prime}-110^{\circ} 00^{\prime}$ east longitude. It belongs to the south of the Qinling Mountains in Shaanxi Province. The climate type is subtropical monsoon climate. The vegetation is mainly dominated by broad-leaved and evergreen broad-leaved mixed forests. The average annual temperature is $12-15^{\circ}$. The annual precipitation is $709-1400 \mathrm{~mm}$. It is necessary to investigate the change tendency of the vegetation coverage in the Qinling Mountains, which provides practical guiding significance for the protection of the ecological environment.

\subsection{Data Source}

The NDVI data sources used in this study are GIMMS NDVI, MODIS NDVI, and SPOT NDVI. The GIMMS NDVI data are based on the global vegetation index change data from NASA Land Data Center from 2000 to 2006 with a spatial resolution of $8 \mathrm{~km}$. The MODIS NDVI data is acquired from the MOD13Q1 data products, which is developed by the NASA MODIS Land Product Group from 2000 to 2013. The spatial resolution is $250 \mathrm{~m}$. The SPOT NDVI data are from the data products obtained by the European Commission's VEGETATION sensor from 2000 to 2013, with a spatial resolution of $1 \mathrm{~km}$. 


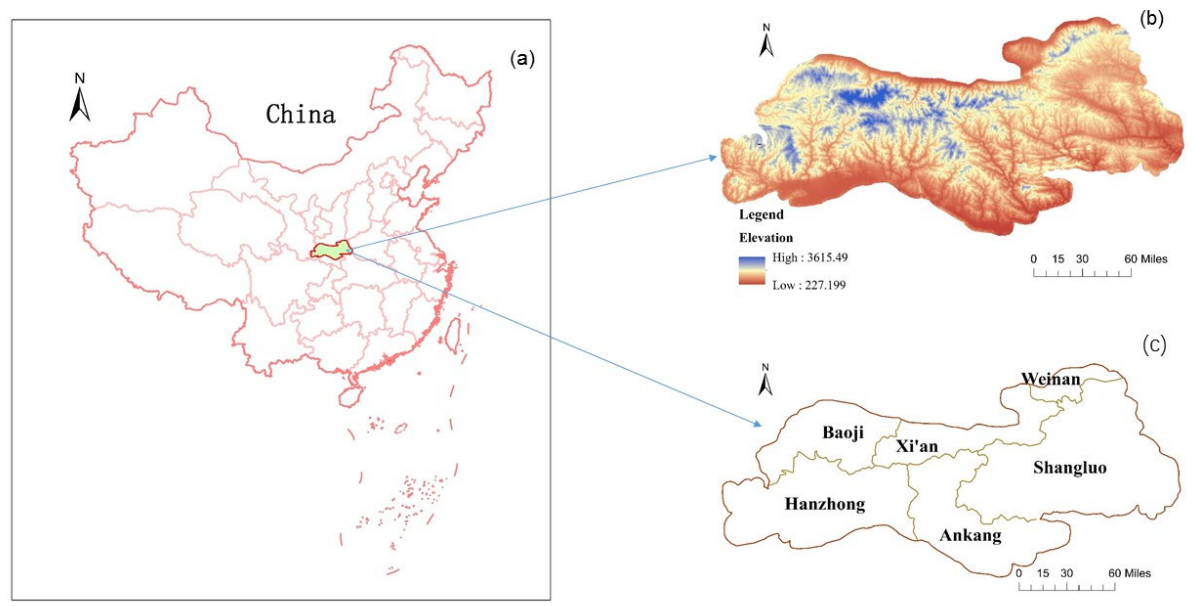

Figure 1. Study Area: (a) Location of the Qinling Mountains in China; (b) The elevation and (c) city boundaries of the study area.

\subsection{Data Processing}

First, three types of NDVI data were subjected to subset extraction, image mosaic, data cropping, and format conversion. Then, the processed data were checked, frame by frame, using the data quality mark. The image cells that do not meet the data quality mark were eliminated. Secondly, three types of NDVI data were processed using maximum value compositing (MVC) by month, which eliminated the impact of clouds and phenological cycles. Then, the spatial resolution of the NDVI data were adjusted to be consistent. The corresponding formulas, such as NDVI $=\mathrm{DN} / 1000$, NDVI $=0.004 \times \mathrm{DN}-0.1$ [50], and NDVI $=$ DN $/ 10,000$ [51], were used in ENVI. The digital number (DN) values of GIMMS, SPOT-VGT, and MODIS were converted into corresponding NDVI values in the corresponding range $(-1 \sim 1)$. Finally, based on the phenological data of the vegetation in the Qinling Mountains, the annual growth season was determined from April to September. The average value of NDVI in each growing season was calculated as the basic data for calculating vegetation coverage.

\section{Methods}

\subsection{Calculation of Vegetation Coverage Degree}

NDVI is the vegetation coverage index, which is widely used in remote sensing. Moreover, the $f_{c}$ is used to evaluate the vegetation coverage degree. The calculation of $f_{c}$ is shown in Equation (1) [52]:

$$
\mathrm{f}_{c}=\frac{N D V I-N D V I_{\text {soil }}}{N D V I_{\text {veg }}-N D V I_{\text {soil }}}
$$

where $N D V I_{\text {veg }}$ is the NDVI value of the image unit covered with only vegetation, and $N D V I_{\text {soil }}$ is the NDVI value of the image unit covered with only soil.

The statistical histogram of the NDVI image was calculated using the gray distribution of NDVI on the entire image. Then, the invalid values were removed. The confidence interval of $99 \%$ was determined for the value of NDVI, which was used to calculate the vegetation coverage degree.

\subsection{Classification of Vegetation Coverage Degree}

In this paper, the forest landscape of the Qinling Mountains area was researched, which used Landsat5 TM images (30 m resolution) to classify landscape types. Figure 2 shows the spatial distribution of forest landscape types in the Qinling Mountains from 2008 to 2013. 

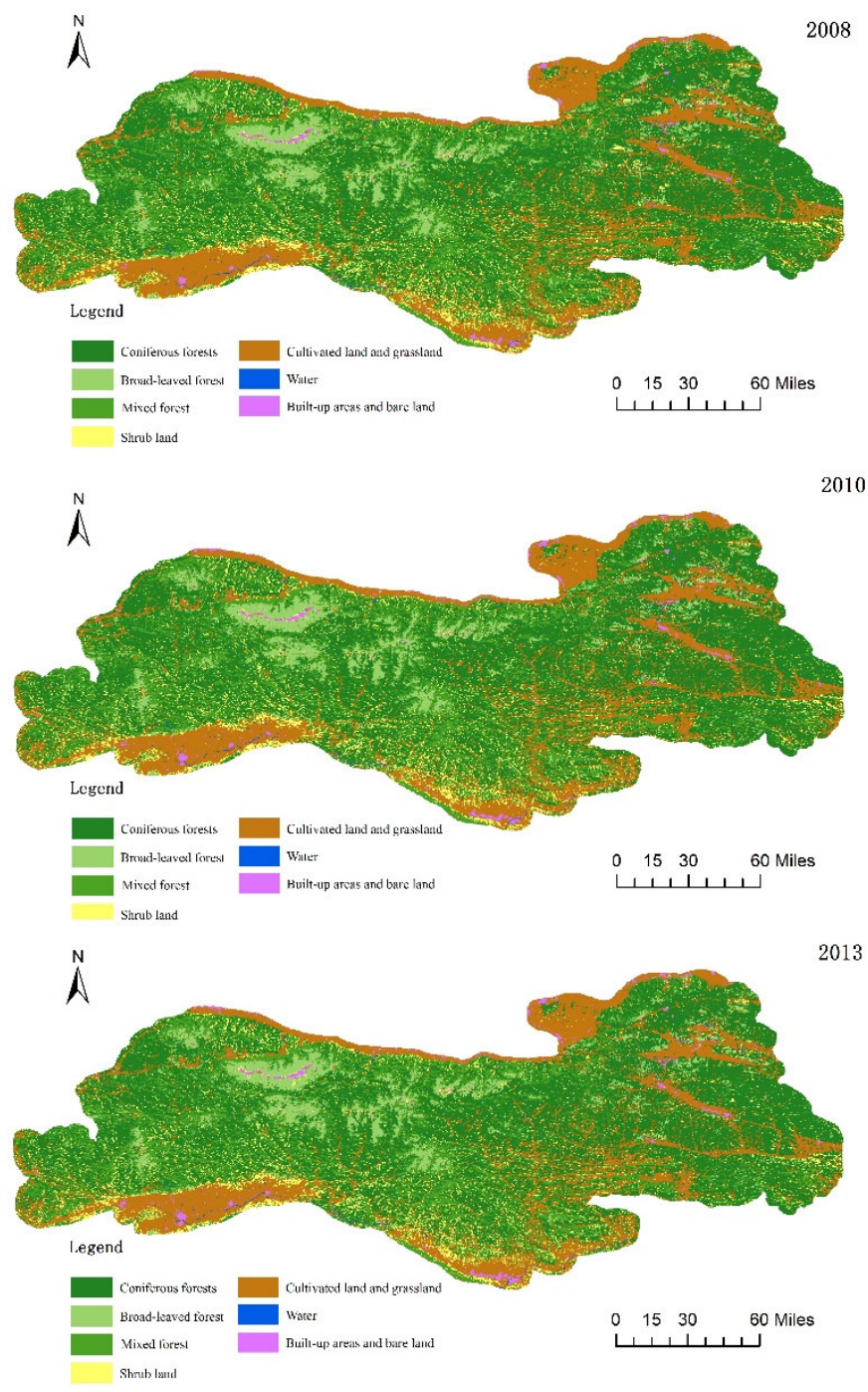

Figure 2. The spatial distribution of forest landscape types in the Qinling Mountains from 2008 to 2013.

As shown in Table 1, the vegetation coverage was classified as 5 classes according to the "Classification Standard for Soil Erosion Classification" issued by the Ministry of Water Resources, and the requirements for vegetation coverage classification were listed in the "Technical Specifications for Soil and Water Conservation" [52]. For example, when the coverage of vegetation in the unit cell is below $15 \%$, it was classified as the low vegetation coverage, which includes the landscape of habitat, water, bare, traffic, and grass.

Table 1. Grading of the coverage of vegetation.

\begin{tabular}{|c|c|c|c|}
\hline No. & $\begin{array}{l}\text { The Grade of the } \\
\text { Vegetation Coverage }\end{array}$ & $\begin{array}{c}\text { The Coverage of } \\
\text { Vegetation }\end{array}$ & Landscape \\
\hline 1 & $\begin{array}{l}\text { Low vegetation } \\
\text { coverage }\end{array}$ & $<15 \%$ & $\begin{array}{l}\text { Habitat, water, bare, } \\
\text { traffic, grass }\end{array}$ \\
\hline 2 & $\begin{array}{c}\text { Middle and low } \\
\text { vegetation coverage }\end{array}$ & $15 \%-40 \%$ & $\begin{array}{c}\text { Grass, woodland, } \\
\text { farmland, sparse wood }\end{array}$ \\
\hline 3 & $\begin{array}{l}\text { Middle vegetation } \\
\text { coverage }\end{array}$ & $40 \%-60 \%$ & $\begin{array}{l}\text { Grass, woodland, other } \\
\text { wood, farmland }\end{array}$ \\
\hline 4 & $\begin{array}{c}\text { Middle and high } \\
\text { vegetation coverage }\end{array}$ & $60 \%-75 \%$ & Shrub, forest \\
\hline 5 & $\begin{array}{l}\text { High vegetation } \\
\text { coverage }\end{array}$ & $>75 \%$ & Shrub, forest \\
\hline
\end{tabular}




\subsection{Kappa Coefficient}

Pearson $\chi^{2}$ is used to evaluate the accuracy of remote sensing data for the dynamic change of vegetation coverage in the study area, which is to confirm that can be applied in the CA-Markov model. The calculation formula of the kappa coefficient is expressed as $[53,54]$,

$$
\chi^{2}=\sum \frac{\left(f_{0}-f_{e}\right)^{2}}{f_{e}}
$$

where $f_{0}$ is the observed value and $f_{e}$ is the expected value. The statistic value of $\chi^{2}$ is compared with the distribution critical value of $\chi^{2}$ with freedom degree of $(m-1)$. If $\chi^{2}>\chi^{2} 0.05(m-1)$, it is indicated that the two quantities are not related.

The kappa coefficient is used to evaluate the macro accuracy of remote sensing data classification and the similarity of two maps, which is calculated using the Crosstable module in IDRISI. The calculation formula of the kappa coefficient is expressed as [55]

$$
\text { Kappa }=\frac{P_{o}-P_{e}}{P_{p}-P_{c}}
$$

where $P_{o}$ is the ratio of correct simulation, $P_{c}$ is the expected correct proportion in the random case, and $P_{p}$ is the ideal proportion of correct simulations (usually $100 \%$ ).

Generally, when kappa $>0.75$, the consistency of the two maps is high and the change is small. When $0.4 \leq k a p p a \leq 0.75$, the consistency of the two maps was general and the changes were obvious. When kappa $<0.4$, the consistency is poor and the variation is large.

\subsection{Prediction of Vegetation Coverage Degree}

The CA-Markov module in the IDRISI Andes was used to predict the vegetation coverage degree. This module combines the CA model and the Markov model to improve the computation efficiency in the simulation of predication $[41,55,56]$. The process is as follows:

(1) The transition area between various vegetation coverage levels from 2008 to 2010 is used as the element of the Markov state transition probability matrix. Based on the probability transition matrix, the vegetation coverage grades in 2013 were predicted.

(2) The $5 \times 5$ cell matrixes around each cell were used as the neighbor cells to form a $5 \times 5$ filter.

(3) The Pearson $\chi^{2}$ test and the kappa accuracy test were performed on the predicted landscape types and the actual landscape types in 2013.

(4) Based on the probability matrix of area transition from 2010 to 2013 and the actual vegetation coverage level in 2013, the grades of vegetation coverage in 2025 were predicated.

\section{Results}

\subsection{Comparison of Three NDVI}

As shown in Table 2, the red light band of the MODIS sensor is $0.62-0.67 \mu \mathrm{m}$. The center value of this band is the maximum absorption value of light in the red band by chlorophyll. Moreover, the sensitivity of chlorophyll to visible light and red light in this band is high. The near infrared band is $0.841-0.876 \mu \mathrm{m}$. This band is the strong near-infrared light reflection region of green vegetation, which avoids the strong moisture absorption bands of vegetation and eliminates the interference of vegetation moisture on the vegetation index. Comparing with SPOT NDVI, the red light band of GIMMS NDVI is narrower, which reduces the sensitivity of chlorophyll to red light radiation. At the same time, the near-infrared band of GIMMS NDVI is wider. As the detected vegetation index is greatly affected by the water of green vegetation, the interference of water vapor makes the average value of GIMMS NDVI smaller than the average value of SPOT NDVI. In addition, MODIS NDVI and SPOT NDVI have a higher spatial resolution, a finer ground surface coverage signal, and a higher ability 
to identify ground objects than that of GIMMS NDVI. Therefore, MODIS NDVI and SPOT NDVI are better than GIMMS NDVI in data accuracy and reliability.

Table 2. Comparison of three normalized difference NDVI products.

\begin{tabular}{|c|c|c|c|c|c|}
\hline & Satellite & Sensor & Bandwidth & $\begin{array}{c}\text { Spatial } \\
\text { Resolution }\end{array}$ & $\begin{array}{c}\text { Temporal } \\
\text { Resolution }\end{array}$ \\
\hline $\begin{array}{l}\text { GIMMS } \\
\text { NDVI }\end{array}$ & $\begin{array}{l}\text { NOAA-16 } \\
\text { NOAA-17 } \\
\text { NOAA-18 }\end{array}$ & AVHRR & $\begin{array}{l}\text { RED: } 0.585-0.680 \mu \mathrm{m} \\
\text { NIR: } 0.730-0.980 \mu \mathrm{m}\end{array}$ & $8 \mathrm{~km}$ & 15 days \\
\hline $\begin{array}{c}\text { MODIS } \\
\text { NDVI }\end{array}$ & TERRA & MODIS & $\begin{array}{l}\text { RED: } 0.620-0.670 \mu \mathrm{m} \\
\text { NIR: } 0.841-0.876 \mu \mathrm{m}\end{array}$ & $250 \mathrm{~m}$ & 1 month \\
\hline $\begin{array}{l}\text { SPOT-VGT } \\
\text { NDVI }\end{array}$ & $\begin{array}{l}\text { SPOT-4 } \\
\text { SPOT-5 }\end{array}$ & VEGETATION & $\begin{array}{l}\text { RED: } 0.61-0.68 \mu \mathrm{m} \\
\text { NIR: } 0.79-0.89 \mu \mathrm{m}\end{array}$ & $1 \mathrm{~km}$ & 10 days \\
\hline
\end{tabular}

Figure 3 shows the pixel-scale differences of GIMMS NDVI, SPOT NDVI, and MODIS NDVI in the Qinling Mountains. The average data in growth season were counted pixel by pixel. For GIMMS NDVI, the distribution of average data in the growth season ranged from 0.455 to 0.735 . The distribution area concentrated in the region from 0.5 to 0.7 , accounting for $91.2 \%$ of the total distribution area. For SPOT NDVI, the distribution of average data in the growth season ranged from 0.36 to 0.80 . The distribution area concentrated in the region from 0.7 to 0.9 , accounting for $91.2 \%$ of the total distribution area. And for MODIS NDVI, the distribution of average data in growth season ranged from 0.31 to 0.873 . The distribution area concentrated in the region from 0.6 to 0.9 , accounting for $91.7 \%$ of the total distribution area. Compared with GIMMS NDVI, MODIS NDVI and SPOT NDVI had very obvious advantages for monitoring the Qinling Mountains with complex and diverse vegetation types.

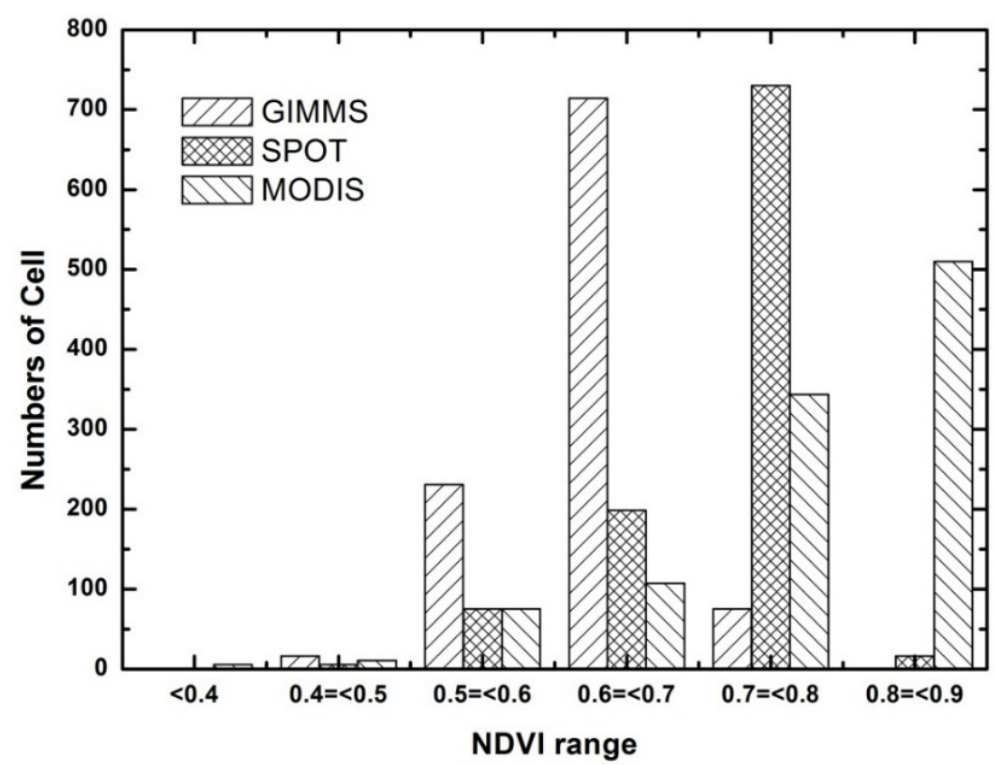

Figure 3. Per-pixel differences between GIMMS NDVI, SPOT NDVI, and MODIS/NDVI for Qinling during 2000-2006.

Table 3 compared the correlation coefficients between the average annual NDVI and NDVIs from April to September for GIMMS NDVI, MODIS NDVI, and SPOT NDVI. For SPOT NDVI and MODIS NDVI, the correlation coefficients between the average annual NDVI and the NDVI values of July, August, and September were greater than $85 \%$. However, for GIMMS NDVI, only the correlation coefficient between the annual average NDVI and the NDVI of August was greater than $80 \%$. This means that, compared with SPOT NDVI and MODIS NDVI, the calculation results of the average growth season data of GIMMS NVDI had a larger deviation to study the vegetation coverage in the Qinling Mountains. In order to ensure that the research results had higher reliability and feasibility, 
the average data in growth season of MODIS NDVI and SPOT NDVI were selected for further analysis of vegetation coverage.

Table 3. Correlation coefficient of annual NDVI and NDVIs from April to September.

\begin{tabular}{cccc}
\hline Month & GIMMS & SPOT & MODIS \\
\hline 4 & 0.29 & 0.43 & 0.60 \\
5 & 0.44 & 0.79 & 0.66 \\
6 & 0.32 & 0.43 & 0.79 \\
7 & 0.28 & 0.87 & 0.93 \\
8 & 0.82 & 0.90 & 0.94 \\
9 & 0.33 & 0.93 & 0.80 \\
\hline
\end{tabular}

\subsection{Grading and Prediction of Vegetation Coverage Using MODIS NDVI}

\subsubsection{Grading of Vegetation Coverage Degree for MODIS NDVI}

The vegetation coverage of the Qinling Mountains area was calculated using the average value of MODIS NVDI in the growing season of 2008, 2010, and 2013. The histograms and statistical results of the images in the Qinling Mountains at different time scales were respectively counted using Compute Statistics function in ENVI 5.1. The NDVI values with a cumulative probability of $5 \%$ and $95 \%$ were used as $N D V I_{\text {veg }}$ and $N D V I_{\text {soil }}$ to calculate vegetation coverage. Based on Equation (1), the vegetation coverage degrees of the Qinling Mountains in 2008, 2010, and 2013 were calculated using the Band Math function in ENVI 5.1. The calculated vegetation coverage degrees were distributed between 0 and 1 . According to vegetation coverage grade, images were processed by density segmentation. Then, they were imported into ArcGIS for processing, which produced the grade image of the vegetation coverage.

Figure 4 shows the spatial distribution of vegetation coverage in the Qinling Mountains. The vegetation coverage was low for the built-up areas in the south of $\mathrm{Xi}^{\prime}$ an, Hanzhong, Shangluo, Ankang, and other cities along the mountainous terrain. The vegetation coverage was moderate in the southeast of the Qinling Mountains, which was dominated by mixed farmland and agro-forestry vegetation. The vegetation coverage was at a low-medium grade in the area between the urban built-up area and the southeast mixed vegetation area, which formed a transition zone from low vegetation coverage to medium vegetation coverage. The south slope of the Qinling Mountains was in the middle and high vegetation coverage and high vegetation coverage grades, as it was an area covered by temperate coniferous and broad-leaved mixed forest, subtropical deciduous broad-leaved forest, and evergreen broad-leaved mixed forest. The vegetation coverage in the Qinling Mountains was in high-grade, reaching more than $50 \%$ in areas with high vegetation coverage. The proportions of low vegetation coverage, middle vegetation coverage, and medium-high vegetation coverage were all above $10 \%$. The proportion of middle and low vegetation coverage was less than $10 \%$. There was little change in the area and proportion of vegetation coverage in different years. The proportion of the low vegetation cover grade area had a tendency to decrease. The area ratio of the middle and middle-high vegetation coverage grades tended to increase. The proportion of the high vegetation coverage grade area had a decreasing trend. Overall, there was a tendency for vegetation coverage in the Qinling Mountains to transform to higher levels of vegetation coverage. In terms of human factors, this may be related to the implementation of the "Natural Protection Forest Project" and the "Returning Cultivated Land to Forests and Grasslands Project" in 2008. 

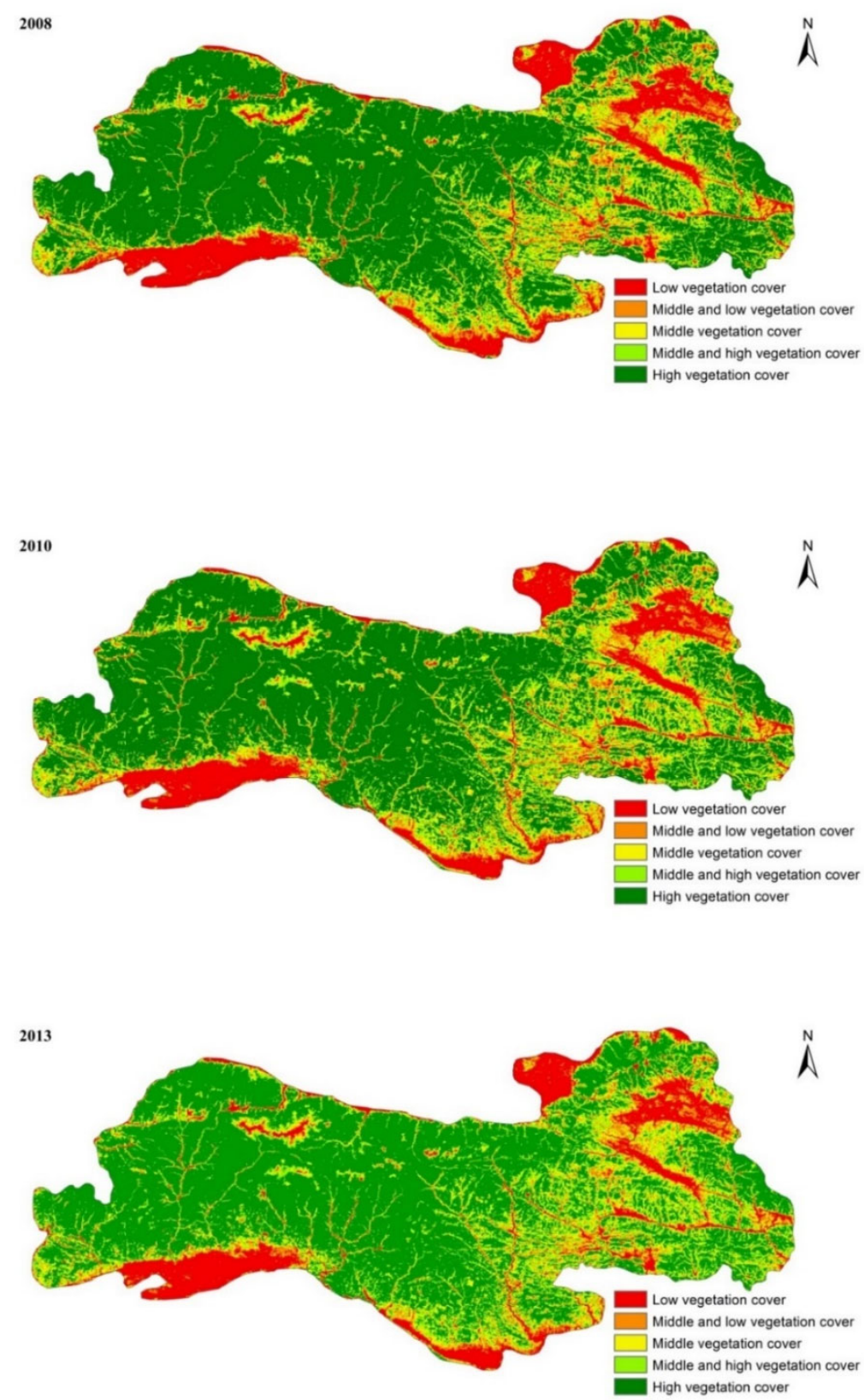

Figure 4. The grade of the vegetation coverage of the Qinling Mountains by MODIS NDVI in 2008, 2010, and 2013.

\subsubsection{Prediction on Vegetation Coverage Using MODIS NDVI}

The MODIS NDVI data in 2008, 2010, and 2013 were processed in IDRISI Andes 17.0 for the prediction of vegetation coverage of the Qinling Mountains. The area transfer matrix of vegetation coverage grade from 2008 to 2010 was taken as the conversion rule. Based on the map of actual vegetation coverage grading in 2010, the vegetation coverage grades in 2013 were simulated and predicted using the CA-Markov model. Then, the Pearson $\chi^{2}$ test results and Kappa coefficient for the actual vegetation coverage grades and simulation map in 2013 were calculated to evaluate the simulation accuracy. The Pearson $\chi^{2}$ index was used to verify the study area without aftereffects. The $\chi^{2}$ was compared with the critical value of $\chi^{2}$ distribution with degree of freedom $(m-1)$. If $\chi^{2}>\chi^{2}{ }_{0.05}(m-1)$, it means that the two vectors were uncorrelated, and there was no aftereffect [28]. The kappa coefficient is generally used to evaluate the classification accuracy of remote sensing data and the similarity of two maps. When the kappa coefficient is greater than 0.75 , 
the consistency between the two maps is considered to be high, which means that the simulation effect is reliable [29]. The analysis was processed in the Crosstab module in IDRISI ANDES 17.0. The simulated Pearson $\chi^{2}$ index was 2,965,547.75000, which was much larger than $\chi^{2}{ }_{0.05}(15)=25$. This means that the two images were independent. The Kappa coefficient was 0.8361 , which indicated that the vegetation coverage grade simulation in 2013 can be used for the CA-Markov module. However, there was a discrepancy between the simulation and the actual distribution of low vegetation coverage and middle and low coverage. Meanwhile, the simulation and the actual distribution of high vegetation coverage and high and middle vegetation were consistent. This may relate to the simulation precision of the CA-Markov model based on NDVI which was relatively lower on the low vegetation coverage compared to the high vegetation coverage. Then, the area transfer matrix of vegetation coverage grade from 2010 to 2013 was taken as the conversion rule. Based on the map of actual vegetation coverage grading in 2013, the vegetation coverage grades in 2025 were simulated using the CA-Markov model. The map of the vegetation coverage grades is shown in Figure 5.

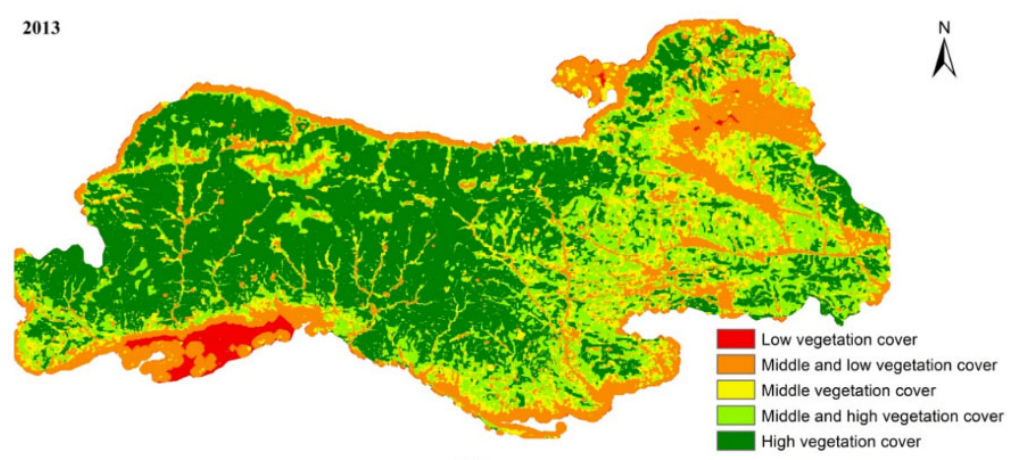

(a)

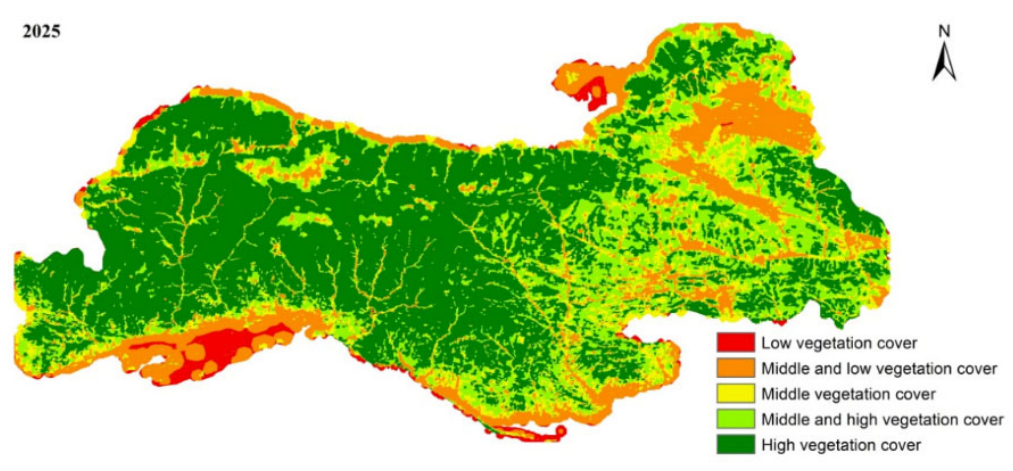

(b)

Figure 5. The prediction of the grade of the coverage of vegetation of the study area by MODDIS NDVI in 2013 and 2025.

As shown in Figure 5, the vegetation coverage grade in the Qinling Mountains has a tendency to transit from the low vegetation coverage grade to the high vegetation coverage grade. The vegetation coverage in the built-up area of the Qinling Mountain is still at a relatively low grade. The built-up area of Shangluo City has almost been transformed into low and middle vegetation coverage grades. In the south of Xi'an, Hanzhong, and Ankang, more than half of the area has also been transformed from low vegetation coverage grades to low and medium vegetation coverage grades. The boundaries of middle and high vegetation coverage grades have a tendency to further expand. The range of high vegetation coverage levels will reduce.

Table 4 shows the prediction of the proportion of various vegetation coverage grades of the Qinling Mountains in 2025. The area and proportion of the low vegetation coverage 
grades will decrease significantly, and transform into low and middle vegetation coverage grades. The area and proportion of the low and middle vegetation coverage grade will increase, while that of middle vegetation coverage grade will increase only slightly. The area and proportion of high vegetation coverage grade will decrease slightly.

Table 4. The grade of the vegetation coverage by MODDIS NDVI in 2008, 2010, 2013, and 2025.

\begin{tabular}{|c|c|c|c|c|c|c|c|c|}
\hline \multirow{2}{*}{$\begin{array}{l}\text { Grade of } \\
\text { Vegetation } \\
\text { Coverage }\end{array}$} & \multicolumn{2}{|c|}{2008} & \multicolumn{2}{|c|}{2010} & \multicolumn{2}{|c|}{2013} & \multicolumn{2}{|c|}{2025} \\
\hline & $\begin{array}{c}\text { Area } \\
\left(\mathrm{km}^{2}\right)\end{array}$ & $\begin{array}{l}\text { Proportion } \\
\text { (\%) }\end{array}$ & $\begin{array}{c}\text { Area } \\
\left(\mathrm{km}^{2}\right)\end{array}$ & $\begin{array}{c}\text { Proportion } \\
(\%)\end{array}$ & $\begin{array}{c}\text { Area } \\
\left(\mathrm{km}^{2}\right)\end{array}$ & $\begin{array}{l}\text { Proportion } \\
\text { (\%) }\end{array}$ & $\begin{array}{c}\text { Area } \\
\left(\mathrm{km}^{2}\right)\end{array}$ & $\begin{array}{l}\text { Proportion } \\
\text { (\%) }\end{array}$ \\
\hline Low & 6490.94 & 11.73 & 6323.19 & 11.43 & 6138.31 & 11.10 & 1263.94 & 2.28 \\
\hline Middle and Low & 4102.25 & 7.42 & 4141.31 & 7.49 & 3892.06 & 7.04 & 7918.25 & 14.31 \\
\hline Middle & 5844.94 & 10.57 & 6413.44 & 11.59 & 6266.94 & 11.33 & 6745.80 & 12.19 \\
\hline Middle and High & 6937.50 & 12.54 & 7993.81 & 14.45 & 8071.81 & 14.59 & $11,239.21$ & 20.32 \\
\hline High & $31,946.75$ & 57.75 & $30,450.63$ & 55.04 & $30,953.25$ & 55.95 & $28,155.17$ & 50.89 \\
\hline
\end{tabular}

\subsection{Grading and Prediction of Vegetation Coverage Using SPOT NDVI}

\subsubsection{Grading of Vegetation Coverage Degree for SPOT NDVI}

The SPOT NDVI data was processed using the method in Section 4.2.1. Figure 6 shows the vegetation coverage grades of the Qinling Mountains in 2008, 2010, and 2013. The spatial distribution result of vegetation coverage grades calculated from SPOT data was highly similar to that from MODIS data. The proportion of the area that was occupied by different grades was also consistent. By comparing the vegetation coverage in various years obtained by SPOT NDVI, the proportion of area in the low vegetation coverage grade area reduced. The proportion of area in the low and medium vegetation coverage grade, the medium vegetation coverage grade, and the medium and high vegetation coverage grade also had a downward trend. The proportion of area in the high vegetation coverage grade area obviously increased. This was a little different with the results from MODIS NDVI as the difference in data spatial resolution and proportion of pure pixels.

\subsubsection{Prediction on Vegetation Using SPOT NDVI}

Based on the method in Section 4.3.1, the simulated Pearson $\chi^{2}$ index using SPOT NDVI was 162,529.09375, which was much larger than $\chi^{2}{ }_{0.05}(15)=25$. This means that the two images were also independent. However, there also was a discrepancy between the simulation and the actual distribution of the low vegetation coverage and the middle and low coverage. Both of the simulations on MODIS NDVI and SPOT NDVI showed lower precision on the low vegetation coverage. Figure 7 shows the vegetation coverage grades of the Qinling Mountains in 2025.

As shown in Figure 7, the change trend of vegetation coverage grades in Qinling Mountain in 2025, predicted from SPOT NDVI data, is consistent with that obtained from the MODIS NDVI data. The low vegetation coverage will transit to low and medium vegetation coverage. Shangluo City will almost be transformed into low and middle vegetation coverage. However, there is only a large part of the area in the south of Xi'an, Hanzhong, and Ankang, which will be converted from low vegetation coverage to lowmiddle vegetation coverage, which is less than half the total area. This is smaller than the area predicted from the results obtained by MODIS NDVI data. The spatial distribution of middle-high vegetation coverage will expand, and the proportion of high vegetation coverage area will decrease slightly, which is also the same as the prediction results obtained by MODIS NDVI data. 

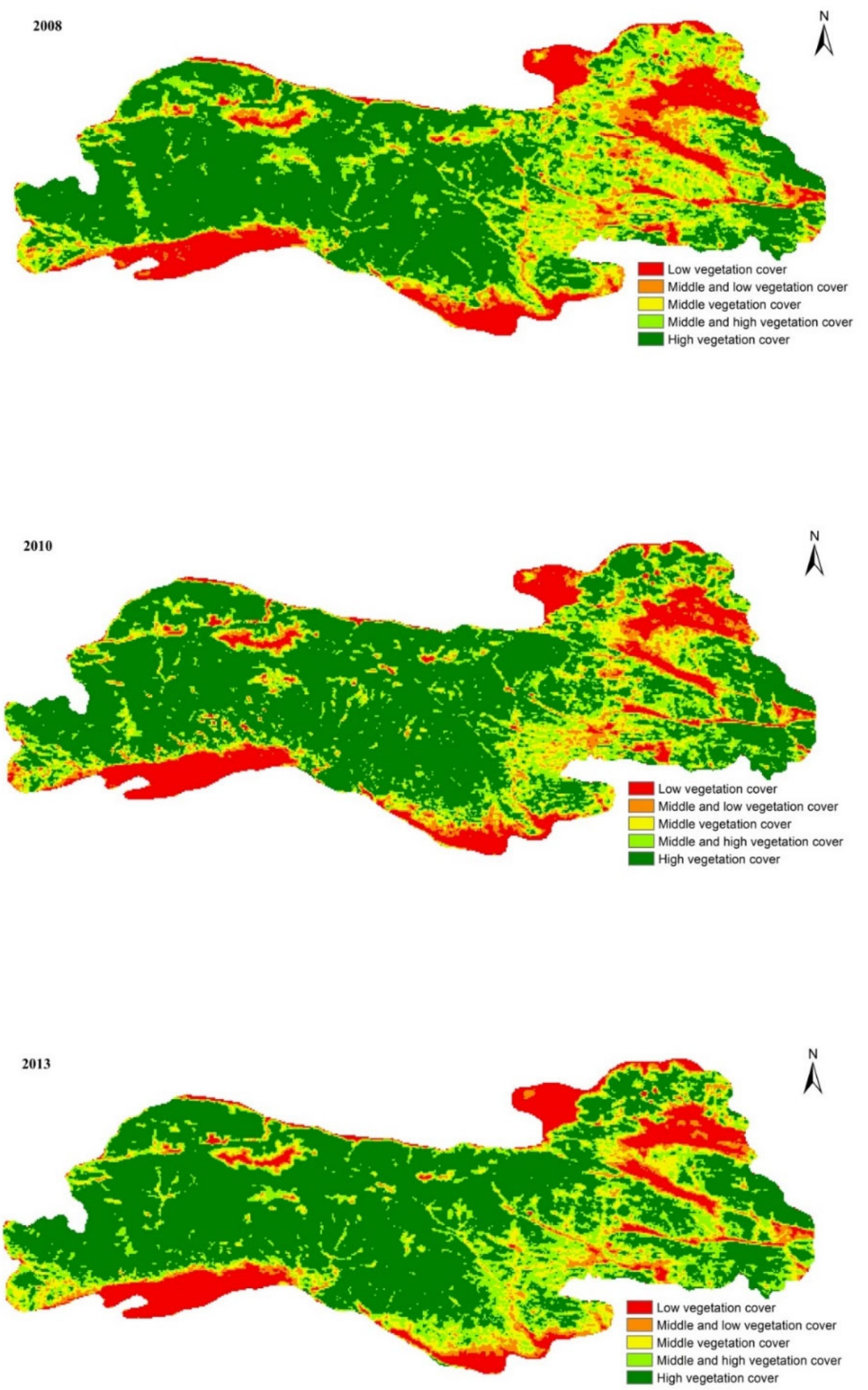

Figure 6. The grade of the vegetation coverage of Qinling Mountain by SPOT NDVI in 2008, 2010 and 2013. 


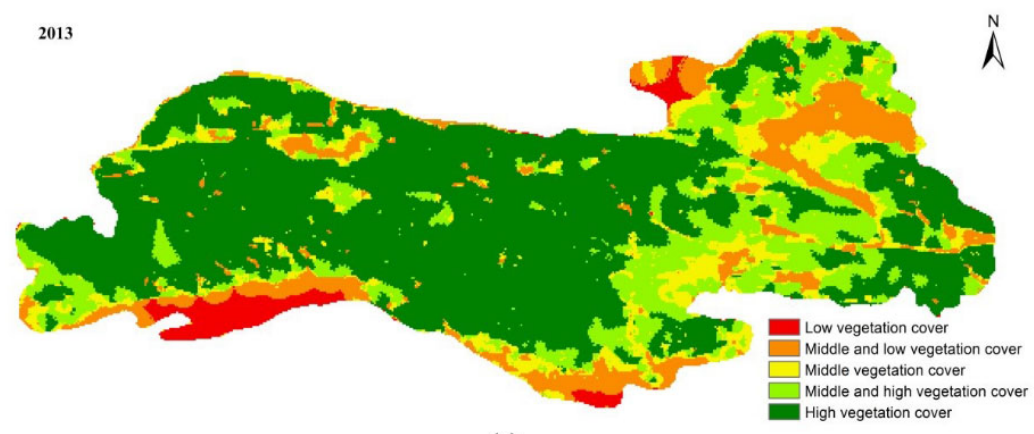

(a)

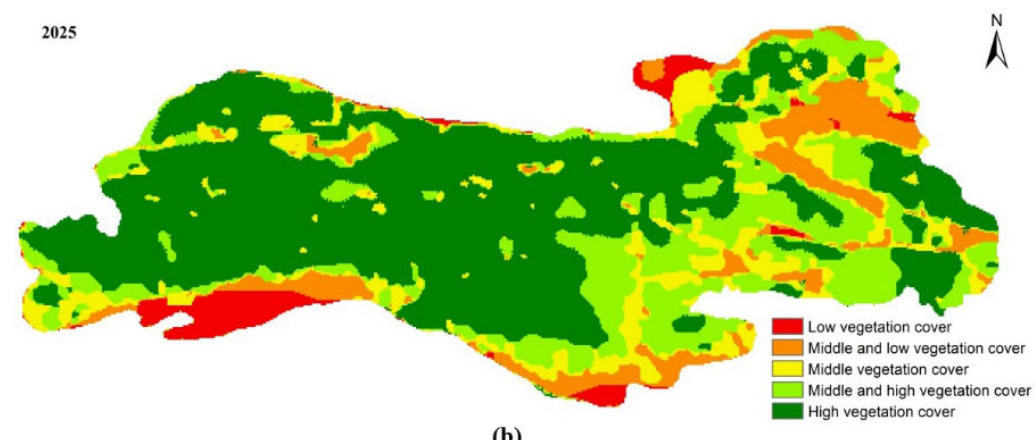

(b)

Figure 7. The prediction of the grade of the vegetation coverage of the Qinling Mountains by SPOT NDVI in 2013 and 2025.

Table 5 shows the prediction of the proportion of various vegetation coverage grades of the Qinling Mountains in 2025 using SPOT NDVI. By comparing the vegetation coverage in various years obtained by SPOT NDVI, the proportion of area in the low vegetation coverage grade area decreases. The proportion of area in the low and medium vegetation coverage grade, the medium and high vegetation coverage grade, and the medium and high vegetation coverage grade also have a downward trend. The proportion of area in the high vegetation coverage grade area obviously increases. This is different from the results of MODIS NDVI as the difference in data spatial resolution and proportion of pure pixels. The degree of transition from low vegetation coverage to middle-low vegetation coverage is not as strong as that predicted by MODIS data. Meanwhile, the area and proportion of low-middle vegetation coverage are also smaller than that predicted by MODIS data. The area and proportion of middle-high vegetation coverage are higher than that that predicted by the MODIS NDVI data.

Table 5. The grade of the vegetation coverage by SPOT NDVI in 2008, 2010, 2013, and 2025.

\begin{tabular}{|c|c|c|c|c|c|c|c|c|}
\hline \multirow{2}{*}{$\begin{array}{l}\text { Grade of } \\
\text { Vegetation } \\
\text { Coverage }\end{array}$} & \multicolumn{2}{|c|}{2008} & \multicolumn{2}{|c|}{2010} & \multicolumn{2}{|c|}{2013} & \multicolumn{2}{|c|}{2025} \\
\hline & $\begin{array}{c}\text { Area } \\
\left(\mathbf{k m}^{2}\right)\end{array}$ & $\begin{array}{c}\text { Proportion } \\
\text { (\%) }\end{array}$ & $\begin{array}{c}\text { Area } \\
\left(\mathrm{km}^{2}\right)\end{array}$ & $\begin{array}{c}\text { Proportion } \\
\text { (\%) }\end{array}$ & $\begin{array}{c}\text { Area } \\
\left(\mathrm{km}^{2}\right)\end{array}$ & $\begin{array}{l}\text { Proportion } \\
\text { (\%) }\end{array}$ & $\begin{array}{c}\text { Area } \\
\left(\mathrm{km}^{2}\right)\end{array}$ & $\begin{array}{c}\text { Proportion } \\
(\%)\end{array}$ \\
\hline Low & 6806.70 & 12.29 & 6181.78 & 11.17 & 5815.54 & 10.50 & 2173.64 & 3.93 \\
\hline Middle and Low & 4380.13 & 7.91 & 3612.34 & 6.52 & 3273.19 & 5.91 & 5442.73 & 9.83 \\
\hline Middle & 7508.80 & 13.56 & 6050.40 & 10.93 & 6055.32 & 10.94 & 7196.75 & 13.00 \\
\hline Middle and High & $10,042.94$ & 18.14 & 8277.42 & 14.95 & 9210.27 & 16.64 & $11,865.94$ & 21.43 \\
\hline High & $26,627.33$ & 48.09 & $31,243.96$ & 56.43 & $31,011.57$ & 56.01 & $28,686.83$ & 51.81 \\
\hline
\end{tabular}

\section{Discussion}

It is important to evaluate various NDVIs for the CA-Markov model. GIMMS NDVI, MODIS NDVI, and SPOT NDVI were compared in terms of their bandwidth, per-pixel difference, and correlation coefficient. The sensitivity of chlorophyll is key feature of the 
sensor for remote sensing. Comparing with MODIS NDVI and SPOT NDVI, the GIMMS NDVI has the narrower red-light band and a wider near-infrared ban, which can be affected by the water of green vegetation. This results in MODIS NDVI and SPOT NDVI being better than GIMMS NDVI in producing more accurate data. Tarnavsky et al. [57] also found that the GIMMS NDVI did not provide reliable parameters for the atypical behaviors in invalidation. Meanwhile, MODIS NDVI and SPOT DVI have higher spatial resolution than that of GIMMS NDVI, which results in better reliability. MODIS NDVI and SPOT NDVI shows potential to monitor the complex and diverse vegetation types in the Qinling Mountains.

The vegetation coverage maps of the Qinling Mountains in 2008 and 2010 were calculated by SPOT NDVI and MODIS NDVI. Based on the CA-Markov model, the predicted vegetation coverage of the Qinling Mountains in 2013 was simulated. By comparing this with the actual vegetation coverage in 2013, the Pearson $\chi^{2}$ index and the kappa coefficient show that the simulation result was reliable. However, the difference in data spatial resolution and the proportion of pure pixels resulted in a little different of the spatial distribution of vegetation coverage grades. Meanwhile, there was a discrepancy between the simulation and the actual distribution of the low vegetation coverage and the middle and low coverage, while the simulation and actual distribution of the high vegetation coverage and the high and middle vegetation were consistent. This may relate to the simulation precision of the Markov model based on NDVI which was relatively lower on the low vegetation coverage compared with the high vegetation coverage. Both of the stimulations on MODIS NDVI and SPOT NDVI showed lower precision on the low vegetation coverage. Moreover, the radiant energy of vegetation received by the sensor is expected to be affected by the water vapor, ozone, and aerosol in the atmosphere. This will then affect the NDVI values in a given year. The red radiation of vegetation is enhanced by the scattering and upstroke radiation induced by atmosphere, while the value of near-infrared radiation decreases after atmospheric attenuation, such as scattering and water vapor absorption. As a result, the radiation contrast between the red and near-infrared bands of vegetation will decrease, which will make the calculated value less than the actual value in NDVI calculation. This will underestimate the total amount of vegetation coverage, which will fail to reflect the situation of land cover. Moreover, the canopy layer, solid, litter, and water will also affect the receiving of the sensor, which will influence the NDVI calculation.

Both of MODIS NDVI and SPOT NDVI showed a tendency for vegetation coverage in the Qinling Mountains to transform to higher levels of vegetation coverage. In terms of human factors, this may be related to the implementation of the "Natural Protection Forest Project" and the "Returning Cultivated Land to Forests and Grasslands Project".

\section{Conclusion}

The vegetation coverage of the Qinling Mountains in 2025 was simulated and predicted using the CA-Markov model. Our conclusions are as follows.

(1) The correlation coefficients of GIMMS NDVI, SPOT NDVI, and MODIS NDVI between the values from April to September and the annual average value were calculated. Compared with GIMMS NDVI, the correlation coefficients of SPOT NDVI and MODIS NDVI in July, August, and September were greater than $80 \%$. SPOT NDVI and MODIS NDVI were used for vegetation coverage grading.

(2) SPOT NDVI and MODIS NDVI were used to grade the vegetation coverage in the Qinling Mountains. Furthermore, the two grading results were consistent. The results showed that the high vegetation coverage in the Qinling Mountains was more than $50 \%$ in area. The proportions of low vegetation coverage, middle vegetation coverage, and middle-high vegetation coverage were all above $10 \%$. The proportion of middle-low vegetation coverage was less than $10 \%$.

(3) In the spatial scale, the vegetation coverage around urban built-up areas that are distributed in a stripe along the mountains is at the lowest level. In addition, the vegetation coverage in the southeast of the Qinling Mountains is dominated by mixed 
farmland and agroforestry vegetation. However, the vegetation coverage in the transition area between the urban built-up area and the mixed vegetation area in the southeast is relatively low, forming a transition zone. The vegetation coverage on the southern slope of the Qinling Mountains is relatively high, which is covered by temperate coniferous and broad-leaved mixed forests, subtropical deciduous broadleaved forests, and evergreen broad-leaved mixed forests. In the time scale, the area ratio of vegetation coverage grade does not change much between years, which has a trend of conversion from low vegetation coverage to low-medium vegetation coverage. For MODIS NDVI, the low vegetation cover grade and the high vegetation cover grade decreases, while the middle vegetation cover grade and the middle-high vegetation cover grade increases.

(4) The vegetation coverage maps of the Qinling Mountains in 2008 and 2010 were calculated by SPOT NDVI and MODIS NDVI. Based on the CA-Markov model, the predicted vegetation coverage of the Qinling Mountains in 2013 was simulated. By comparing with the actual vegetation coverage in 2013, the Pearson $\chi^{2}$ index and the kappa coefficient showed that the simulation result is reliable.

(5) Based on the CA-Markov model, the predicted vegetation coverage of the Qinling Mountains in 2025 was simulated using the vegetation coverage maps in 2008, 2010, and 2013. The prediction results shows that the low vegetation coverage transits to middle-low vegetation coverage. The proportion of middle and middle-high vegetation coverage increases. The high vegetation coverage is stable.

(6) The growth and distribution of vegetation are affected by many factors. The influence of atmospheric conditions and other environmental factors on the NDVI value is not considered in this study, and can therefore be further discussed in the future research process.

(7) The data selected in this paper are from 2008, 2010, and 2013. The interval and span of time are small. Although the research results can show a certain trend of change, a longer time scale should be selected to achieve more obvious research effects in further work.

(8) The resolution of remote sensing images is a key feature to affect the accuracy of prediction. Higher-resolution remote sensing images should be used in future research. The smaller the cellular scale, the higher the accuracy of the prediction results in quantity and space.

Author Contributions: Conceptualization, Y.Z., J.L. (Jianchao Liu), and L.C.; methodology, Y.Z., L.C., and H.W.; validation, formal analysis and investigation, L.C.; resources, L.H., J.L. (Juan Li), and Z.S.; writing —original draft preparation, L.C.; writing—review and editing, Y.Z. All authors have read and agreed to the published version of the manuscript.

Funding: This work was jointly supported by National Natural Science Foundation of China (grant No. 31670549 \& 31170664), the Fund Project of Key Laboratory of Degraded and Unused Land Consolidation Engineering, the Ministry of Natural and Resources (Program No. SXDJ2019-03), and the Fundamental Research Funds for the Central Universities, CHD (300102270206 \& 300102278403).

Data Availability Statement: The GIMMS NDVI data is based on the global vegetation index change data from NASA Land Data Center from 2000 to 2013 (http:/ / westedc.westgis.ac.cn accessed on 4 October 2021). The MODIS NDVI data is acquired from the MOD13Q1 data products, which is developed by the NASA MODIS Land Product Group from 2002 to 2013 (http:/ / lpdaac.usgs.gov accessed on 4 October 2021). The SPOT NDVI data is from the data products obtained by the European Commission's VEGETATION sensor from 2000 to 2013 (http:/ / westdc.westgis.ac.cn/ accessed on 4 October 2021, http:/ / free.vgt.vito.be/ accessed on 4 October 2021).

Acknowledgments: We would like to thank all editors and reviewers for their profound comments, which help us to improve the quality of this paper.

Conflicts of Interest: The authors declare no conflict of interest. 


\section{References}

1. Fu, B.; Wang, S.; Liu, Y.; Liu, J.; Liang, W.; Miao, C. Hydrogeomorphic ecosystem responses to natural and anthropogenic changes in the loess plateau of China. Annu. Rev. Earth Planet. Sci. 2017, 45, 223-243. [CrossRef]

2. Yuan, J.; Xu, Y.; Xiang, J.; Wu, L.; Wang, D. Spatiotemporal variation of vegetation coverage and its associated influence factor analysis in the Yangtze River Delta, eastern China. Environ. Sci. Pollut. Res. 2019, 26, 32866-32879. [CrossRef]

3. Zhang, P.; Cai, Y.; Yang, W.; Yi, Y.; Yang, Z.; Fu, Q. Multiple spatio-temporal patterns of vegetation coverage and its relationship with climatic factors in a large dam-reservoir-river system. Ecol. Eng. 2019, 138, 188-199. [CrossRef]

4. Noszczyk, T.; Rutkowska, A.; Hernik, J. Exploring the land use changes in Eastern Poland: Statistics-based modeling. Hum. Ecol. Risk Assess. Int. J. 2020, 26, 255-282. [CrossRef]

5. Du, J.; Quan, Z.; Fang, S.; Liu, C.; Wu, J.; Fu, Q. Spatiotemporal changes in vegetation coverage and its causes in China since the Chinese economic reform. Environ. Sci. Pollut. Res. 2019, 27, 1144-1159. [CrossRef]

6. Du, J.; Fu, Q.; Fang, S.; Wu, J.; He, P.; Quan, Z. Effects of rapid urbanization on vegetation cover in the metropolises of China over the last four decades. Ecol. Indic. 2019, 107, 105458. [CrossRef]

7. Feng, D.; Wang, J.; Fu, M.; Liu, G.; Zhang, M.; Tang, R. Spatiotemporal variation and influencing factors of vegetation cover in the ecologically fragile areas of China from 2000 to 2015: A case study in Shaanxi Province. Environ. Sci. Pollut. Res. 2020, 26, 28977-28992. [CrossRef] [PubMed]

8. Gao, H.; Wu, Z.; Jia, L.; Pang, G. Vegetation change and its influence on runoff and sediment in different landform units, Wei River, China. Ecol. Eng. 2019, 141, 105609. [CrossRef]

9. Ibarrola-Ulzurrun, E.; Marcello, J.; Gonzalo-Martín, C.; Martín-Esquivel, J.L. Temporal dynamic analysis of a mountain ecosystem based on multi-source and multi-scale remote sensing data. Ecosphere 2019, 10, e02708. [CrossRef]

10. Xue, J.; Su, B. Significant remote sensing vegetation indices: A review of developments and applications. J. Sens. 2017, 2017, 1-17. [CrossRef]

11. Yuan, W.; Wu, S.; Hou, S.; Xu, Z.; Lu, H. Normalized difference vegetation index-based assessment of climate change impact on vegetation growth in the humid-arid transition zone in northern China during 1982-2013. Int. J. Clim. 2019, 39, 5583-5598. [CrossRef]

12. Caballero-Gil, P.; Fuster-Sabater, A.; Pazo-Robles, M. Using linear difference equations to model nonlinear cryptographic sequences. Int. J. Nonlinear Sci. Numer. Simul. 2010, 11, 165-172. [CrossRef]

13. Koomen, E.; Rietveld, P.; de Nijs, T. Modelling land-use change for spatial planning support. Ann. Reg. Sci. 2008, 42, 1-10. [CrossRef]

14. Noszczyk, T. A review of approaches to land use changes modeling. Hum. Ecol. Risk Assess. Int. J. 2019, 25, 1377-1405. [CrossRef]

15. Wu, D.; Liu, J.; Zhang, G.; Ding, W.; Wang, W.; Wang, R. Incorporating spatial autocorrelation into cellular automata model: An application to the dynamics of Chinese tamarisk (Tamarix chinensis Lour.). Ecol. Model. 2009, 220, 3490-3498. [CrossRef]

16. Schweitzer, C.; Priess, J.; Das, S. A generic framework for land-use modelling. Environ. Model. Softw. 2011, 26, 1052-1055. [CrossRef]

17. Ding, W.-J.; Wang, R.-Q.; Wu, D.-Q.; Liu, J. Cellular automata model as an intuitive approach to simulate complex land-use changes: An evaluation of two multi-state land-use models in the Yellow River Delta. Stoch. Environ. Res. Risk Assess. 2012, 27, 899-907. [CrossRef]

18. Cao, Y.; Zhang, X.; Fu, Y.; Lu, Z.; Shen, X. Urban spatial growth modeling using logistic regression and cellular automata: A case study of Hangzhou. Ecol. Indic. 2020, 113, 106200. [CrossRef]

19. Yang, X.; Chen, R.; Zheng, X. Simulating land use change by integrating ANN-CA model and landscape pattern indices. Geomat. Nat. Hazards Risk 2015, 7, 918-932. [CrossRef]

20. Valencia, V.H.; Levin, G.; Hansen, H.S. Modelling the spatial extent of urban growth using a cellular automata-based model: A case study for Quito, Ecuador. Geogr. Tidsskr. J. Geogr. 2020, 120, 156-173. [CrossRef]

21. Kim, I.; Kwon, H. Assessing the impacts of urban land use changes on regional ecosystem services according to urban green space policies via. the patch-based cellular automata model. Environ. Manag. 2021, 67, 192-204. [CrossRef]

22. Ke, X.; Zheng, W.; Zhou, T.; Liu, X. A CA-based land system change model: Landscape. Int. J. Geogr. Inf. Sci. 2017, 31, 1798-1817. [CrossRef]

23. Lanzer, A.T.S.; Pillar, V.D. Probabilistic cellular automaton: Model and application to vegetation dynamics. Community Ecol. 2002, 3, 159-167. [CrossRef]

24. Lagarias, A. Urban sprawl simulation linking macro-scale processes to micro-dynamics through cellular automata, an application in Thessaloniki, Greece. Appl. Geogr. 2012, 34, 146-160. [CrossRef]

25. Moreno, N.; Wang, F.; Marceau, D.J. Implementation of a dynamic neighborhood in a land-use vector-based cellular automata model. Comput. Environ. Urban Syst. 2009, 33, 44-54. [CrossRef]

26. Veldkamp, A.; Verburg, P.; Kok, K.; De Koning, G.; Priess, J.; Bergsma, A. The need for scale sensitive approaches in spatially explicit land use change modeling. Environ. Model. Assess. 2001, 6, 111-121. [CrossRef]

27. Perry, G.L.; Enright, N.J. Spatial modelling of vegetation change in dynamic landscapes: A review of methods and applications. Prog. Phys. Geogr. Earth Environ. 2006, 30, 47-72. [CrossRef]

28. Hall, F.G.; Botkin, D.B.; Strebel, D.E.; Woods, K.D.; Goetz, S.J. Large-scale patterns of forest succession as determined by remote sensing. Ecology 1991, 72, 628-640. [CrossRef] 
29. Halmy, M.W.A.; Gessler, P.E.; Hicke, J.A.; Salem, B. Land use/land cover change detection and prediction in the north-western coastal desert of Egypt using Markov-CA. Appl. Geogr. 2015, 63, 101-112. [CrossRef]

30. Sinha, P.; Kumar, L. Markov land cover change modeling using Pairs of time-series satellite images. Photogramm. Eng. Remote. Sens. 2013, 79, 1037-1051. [CrossRef]

31. Biswas, M.; Banerji, S.; Mitra, D. Land-use-land-cover change detection and application of Markov model: A case study of Eastern part of Kolkata. Environ. Dev. Sustain. 2019, 22, 4341-4360. [CrossRef]

32. Ababneh, A.; Al-Saad, S.; Al-Shorman, A.; Al Kharouf, R. Land use change at the historical tourist attractions of Umm Qais, Jordan: GIS and Markov chain analyses. Int. J. Hist. Archaeol. 2018, 23, 235-259. [CrossRef]

33. Das, S.; Sarkar, R. Predicting the land use and land cover change using Markov model: A catchment level analysis of the Bhagirathi-Hugli River. Spat. Inf. Res. 2019, 27, 439-452. [CrossRef]

34. Huang, Y.; Nian, P.; Zhang, W. The prediction of interregional land use differences in Beijing: A Markov model. Environ. Earth Sci. 2014, 73, 4077-4090. [CrossRef]

35. Paul, S.S.; Li, J.; Wheate, R.; Li, Y. Application of object oriented image classification and Markov chain modeling for land use and land cover change analysis. J. Environ. Inform. 2018, 31, 30-40. [CrossRef]

36. Balzter, H. Markov chain models for vegetation dynamics. Ecol. Model. 2000, 126, 139-154. [CrossRef]

37. Behera, M.D.; Borate, S.N.; Panda, S.N.; Behera, P.R.; Roy, P.S. Modelling and analyzing the watershed dynamics using cellular automata (CA)-Markov model—a geo-information based approach. J. Earth Syst. Sci. 2012, 121, 1011-1024. [CrossRef]

38. Adhikari, S.; Southworth, J. Simulating forest cover changes of bannerghatta national park based on a CA-Markov model: A remote sensing approach. Remote. Sens. 2012, 4, 3215-3243. [CrossRef]

39. Chu, L.; Sun, T.; Wang, T.; Li, Z.; Cai, C. Evolution and prediction of landscape pattern and habitat quality based on CA-Markov and InVEST model in hubei section of three gorges reservoir area (TGRA). Sustainability 2018, 10, 3854. [CrossRef]

40. Kityuttachai, K.; Tripathi, N.K.; Tipdecho, T.; Shrestha, R. CA-Markov analysis of constrained coastal urban growth modeling: Hua Hin Seaside City, Thailand. Sustainability 2013, 5, 1480-1500. [CrossRef]

41. Sang, L.; Zhang, C.; Yang, J.; Zhu, D.; Yun, W. Simulation of land use spatial pattern of towns and villages based on CA-Markov model. Math. Comput. Model. 2011, 54, 938-943. [CrossRef]

42. Al-Shaar, W.; Gérard, J.A.; Nehme, N.; Lakiss, H.; Barakat, L.B. Application of modified cellular automata Markov chain model: Forecasting land use pattern in Lebanon. Model. Earth Syst. Environ. 2021, 7, 1321-1335. [CrossRef]

43. Kamusoko, C.; Aniya, M.; Adi, B.; Manjoro, M. Rural sustainability under threat in Zimbabwe-simulation of future land use/cover changes in the Bindura district based on the Markov-cellular automata model. Appl. Geogr. 2009, 29, 435-447. [CrossRef]

44. Tariq, A.; Shu, H. CA-Markov chain analysis of seasonal land surface temperature and land use landcover change using optical multi-temporal satellite data of Faisalabad, Pakistan. Remote. Sens. 2020, 12, 3402. [CrossRef]

45. Du, Y.-K.; Yan, Q.; Luo, C.-F. Monitoring and predicting the changes of vegetation coverage in Shijiazhuang from 1995 to 2015. In 2016 IEEE International Geoscience and Remote Sensing Symposium (IGARSS); IEEE: New York, NY, USA, 2016 ; pp. $2324-2327$.

46. Rimal, B.; Zhang, L.; Keshtkar, H.; Haack, B.N.; Rijal, S.; Zhang, P. Land use/land cover dynamics and modeling of urban land expansion by the integration of cellular automata and Markov chain. ISPRS Int. J. Geo-Inf. 2018, 7, 154. [CrossRef]

47. Wu, S.; Gao, X.; Lei, J.; Zhou, N.; Wang, Y. Spatial and temporal changes in the normalized difference vegetation index and their driving factors in the desert/grassland biome transition zone of the Sahel region of Africa. Remote. Sens. 2020, 12, 4119. [CrossRef]

48. Jamali, A.A.; Naeeni, M.A.M.; Zarei, G. Assessing the expansion of saline lands through vegetation and wetland loss using remote sensing and GIS. Remote. Sens. Appl. Soc. Environ. 2020, 20, 100428. [CrossRef]

49. Wang, L.; Yu, D.; Liu, Z.; Yang, Y.; Zhang, J.; Han, J.; Mao, Z. Study on NDVI changes in Weihe Watershed based on CA-Markov model. Geol. J. 2018, 53, 435-441. [CrossRef]

50. Maisongrande, P.; Duchemin, B.; Dedieu, G. Vegetation/spot: An operational mission for the Earth monitoring; presentation of new standard products. Int. J. Remote. Sens. 2004, 25, 9-14. [CrossRef]

51. Hute, A.; Justice, C.; Leewem, W. Modis Vegetation Index (MODIS13) Algorithm Theoretical Basis Document; NASA Press: New York, NY, USA, 1996.

52. Wang, P. Study on Temporal and Spatial Variation of the Vegetation Coverage in the Upper Reaches of Dadu River' Based on $3 S$ Technology; Sichuan Agricultural University: Chengdu, China, 2012.

53. Li, X.; Liang, C.; Wang, Y. Predicting landscape patterns of Lianhe Delta Wetland by CA-Markov model. Env. Sci. Tech. 2013, 36, 188-192.

54. Georgep, M. Riparian Landscape; Cambridge University: Cambridge, UK, 1993.

55. Zheng, Q.; Luo, G.; Zhou, D. Prediction of landscape patterns in Ili River Delta based on CA-Markov model. Chin. J. Appl. Ecol. 2010, 21, 873-882.

56. Guan, D.; Li, H.; Inohae, T.; Su, W.; Nagaie, T.; Hokao, K. Modeling urban land use change by the integration of cellular automaton and Markov model. Ecol. Model. 2011, 222, 3761-3772. [CrossRef]

57. Tarnavsky, E.; Garrigues, S.; Brown, M. Multiscale geostatistical analysis of AVHRR, SPOT-VGT, and MODIS global NDVI products. Remote Sens. Environ. 2008, 112, 535-549. [CrossRef] 